\title{
Assessing the Educational Needs of Mental Health Nurses Working in an Adolescent Inpatient Psychiatric Ward in Japan
}

\author{
Masue Inoue, RN, MA, MN, Letitia Del Fabbro, RN, BHIthSc (Hons), MPH, and Marion Mitchell, PhD \\ Masue Inoue RN, MA, MN, is Assistant Professor, School of Nursing, Chiba University, Chiba, Japan. Letitia Del Fabbro, RN, BHIthSc (Hons), MPH, is ••, \\ Griffith Health Institute, Logan Campus, Meadowbrook, Queensland, Australia. Marion Mitchell, PhD, is Principal Research Fellow, Griffith Health \\ Institute, Research Centre for Clinical and Community Practice Innovation, Griffith University, and Nurse Practice Development Unit, Princess Alexandra \\ Hospital, Queensland, Australia.
}

\begin{abstract}
Search terms:
Child and adolescent mental health nursing, continuing education, family-centered care, needs analysis, nominal group technique, professional development
\end{abstract}

Author contact:

m.inoue@chiba-u.jp, with a copy to the Editor: poster@uta.edu

doi: 10.1111/j.1744-6171.2012.00335.x
PROBLEM: In Japan, preregistration education is not sufficient to prepare nurses to work as child adolescent mental health nurses.

METHODS: Nominal group technique (NGT) using focus group discussions, and Knowles' Adult Learning Theory, were used to examine the continuing educational needs of nurses in a Japanese adolescent mental health unit.

FINDINGS: Nurses caring for adolescent patients with mental health issues need continuing education. This research demonstrates the utility of nominal group technique in needs analysis in this context.

CONCLUSIONS: Educational priorities include instruction on patients' developmental stage, promoting patient self-sufficiency, and strategies for meeting the needs of families. A family-centered care approach is recommended.

\section{Introduction}

3 In many parts of the world, the needs of child and adolescent mental health patients are not being met, and the education of nurses working in this specialty is not adequate in many countries, too (World Health Organization, 2005). Japan, as in other 4 parts of the world, has recently seen an increase in the prevalence of social problems, including domestic violence, child abuse, and family maladjustment, each of which affects the behavior of children and adolescents; in Japan, this has manifested in increased rates of truancy, bullying, classroom disruption, and delinquency that have increased rapidly in Japan in recent years (Yamazaki, 2004). When mental illness is added to this behavior profile, the result is a very complex scenario for the provision of health care for these young individuals (Saito, 2005). Current healthcare services, including the nursing workforce, struggle to meet the needs of these young clients with complex health needs. It is imperative that child and adolescent mental health nurses are sufficiently prepared educationally to meet the challenges to promote optimal patient care

5 (Sugiyama, 2005; Yamazaki, 2008). In the hospital setting, this can be facilitated by professional continuing education.

\section{Continuing Education}

In 2001 in Japan, approximately $90 \%$ of hospitals had an in-service education system (Japanese Nursing Association
[JNA], 2001). Continuing education is an important mechanism for addressing nurses' education needs, and in-service education is ". . . the most representative system of continuing nursing education" in Japan (Funashima, Miura, \& Kameoka, 2005, p. 13). Despite the prevalence of in-service education, little is known about the focus of this education, in particular the educational topics delivered and the educational needs of child and adolescent mental health nurses.

Two relevant studies have examined the educational needs of child and adolescent mental health professionals (Dogra \& Vostanis, 2007; Jones, 2004). Dogra and Vostanis (2007) had a broad focus which included all professionals involved with child and adolescent mental health services in a diverse community in the United Kingdom. Although over half of participants thought that their present training was not satisfactory, they could not clearly identify their own educational needs. There was no pattern evident between the different professional groups within the small sample $(n=17)$; however, the authors considered the study provided participates with an opportunity to begin to explore their needs and those of their community (Dogra \& Vostanis, 2007).

On the other hand, Jones (2004) conducted a large study, also in the United Kingdom, with 25 nurses participating in focus groups which informed a survey exploring the postregistration education and training needs of nurses working with children and young people with mental health problems. Of the 1,463 surveys sent out, 633 (43\%) were returned. Key 
features of the findings included, among others, the need for further education on risk management, improved patient assessment techniques, therapeutic skills and understanding, and working with families. The survey method identified important areas for education and training for this group; however, Japanese nurses may feel quite differently to the U.K. nurses, due to potential differences in both the child and adolescent mental health services and nursing education in the two countries.

\section{Adult Learning Theory}

Major nursing associations, the JNA (2000) and the American Nurses Association (1994) agree that continuing education should be conducted within an adult learning theoretical framework. The identification of educational needs is the initial step of a cyclical process contributing to an educational strategy of an organization (Pedder, 1998). A needs analysis of employees, preparedness for their required tasks, and identification of knowledge and skill gaps provides an important framework for the strategic provision of suitable educational interventions (Knowles, 1980; O’Shea \& Spike, 2005). Therefore, a needs analysis is a vital component to ensure that the content of educational programs is appropriate and that educational programs match the clinical areas in which they are to be delivered (Brennan, 2006).

Once learning needs have been identified, educational activities can be developed using an adult learning theory such as Knowles' Adult Learning Theory (1973 and 1980). The use of Adult Learning Theory in education enables the development of competencies, knowledge, and abilities, supporting personnel to do the work required and to accomplish the goals of the organizations in a way that is meaningful to the learners (Knowles, Holton, \& Swanson, 2005).

\section{Nominal Group Technique}

Nominal group technique (NGT) (O’Neil \& Jackson, 1983) is a way to identify needs that facilitate the fair and equal representation of the viewpoint of each participant. In Japan, hierarchy within the workplace is quite pronounced and NGT offers a mechanism for countering the power attributed to senior positions, particularly when research studies involve participants of differing degrees of seniority. NGT equally privileges the views and opinions of less senior participants. It was for this reason that NGT was used to identify the educational needs of psychiatric nurses of adolescent patients in order to inform the development of future unit-based education programs.

\section{Methodology}

NGT (Delbecq, Van de Ven, \& Gutsfson, 1975; O’Neil \& Jackson, 1983), using focus group discussions, was utilized to gather the needs of this group. Results from the NGT needs analysis will be reported here. Ethical approval for the study was received by both the site hospital and university human research ethics committees prior to the study's commencement.

\section{Site and Sampling}

This study was conducted within one adolescent ward with 29 beds at a psychiatric hospital in Japan. Purposeful grouping of the sample was undertaken in order to facilitate homogeneity within each focus group (Krueger \& Casey, 2009) and to facilitate open communication among group members. All staff nurses $(n=18)$ were informed of the proposed project in order to avoid gatekeeper bias, thus providing all with an equal opportunity to participate (Holloway \& Wheeler, 2002/ 2006).

\section{Procedure}

The research was conducted in the native language of the participants and primary researcher-Japanese. Following informed written consent, the nurses were divided into two focus groups (Group A and Group B), with those of similar age, years of nursing work experience, and nursing work experience specifically in the child or adolescent mental health setting grouped together. One participant was a notetaker to support the researcher; the note-taker freely consented to participate in this position for both focus groups and his role was to make verbatim notes or record points of interest during the focus groups, adding to the other forms of data collection. The researcher worked in the ward and as such was an "insider researcher." All attempts were made to reduce the possibility that she brought her own beliefs and values to influence group discussions (Hewitt-Taylor, 2002).

NGT (Delbecq et al., 1975; O’Neil \& Jackson, 1983) was used to examine the needs of participants in the two focus groups; this was conducted in a private conference room in the adolescent ward. For research purposes, NGT incorporates eight stages (O’Neil \& Jackson, 1983). Initially for this project, each participant was asked to generate his/her own responses to the question: "What areas of your practice would you like to improve?" Participants were asked to write down their ideas. During the focus group sessions, each participant, in turn, was asked to provide one or more areas from his/her list which was written onto a flip chart by the researcher. Next, participants were asked to check whether or not each listed area of practice made sense to them. As a group, they collectively merged similar areas to develop a discrete master list. This involved a process of collapsing areas where meaning overlapped or where areas were congruent with, or contained within, another area. The group discussed all the identified areas, and as a group they were asked to prioritize in order of 
Table 1. NGT Ranking of Areas for Improvement by Group A (Less Experienced Group) and Group B (More Experienced Group)

\begin{tabular}{|c|c|c|c|}
\hline Rank & Areas of your practice you would like to improve & $\begin{array}{l}\text { Group A ranking } \\
\text { (Scores) } \\
(n=6)\end{array}$ & $\begin{array}{l}\text { Group B ranking } \\
\text { (Scores) } \\
(n=8)\end{array}$ \\
\hline 1 & $\begin{array}{l}\text { Knowledge of normal development, mental illness, and disorders in childhood and } \\
\text { adolescence }\end{array}$ & $1(5,5,5,5,5,5)$ & $1(5,5,5,5,5,5,4)$ \\
\hline 2 and 3 & $\begin{array}{l}\text { Understanding the psychology of family with children who have mental illness, responding } \\
\text { to it, and education of patient's parents }\end{array}$ & $2(3,1,3,4,4,3)$ & $3(2,3,1,1,5,1,3,1)$ \\
\hline 2 & Nursing care of patients with developmental disorders & & $2(4,4,4,2,1,4)$ \\
\hline 3 & Communication skill toward patients and families & $3(3,4,2)$ & \\
\hline 4 & A way of nursing to promote patients becoming self-sufficient & & $4(1,3,4,4,3)$ \\
\hline 4 & Making sense of a common purpose in nursing individual patients-Teamwork & $4(4,2,2)$ & \\
\hline 5 & Relaxation methods for patient treatment & $5(4,3)$ & \\
\hline 5 & $\begin{array}{l}\text { Nursing care and techniques that promote understanding and knowledge of abused } \\
\text { children and how they establish relationships with others }\end{array}$ & & $5(3,2,3,2,2)$ \\
\hline 6 & Overcoming nurses' lack of confidence in caring for adolescent psychiatric patients & $6(4)$ & \\
\hline 6 & Nursing technique to help engage patients in group play & & $6(3,5)$ \\
\hline 7 & A way of controlling nurse's negative feeling toward patients & $7(2,2)$ & \\
\hline 7 & Teamwork (mental health support among staff) & & $7(3,4)$ \\
\hline 8 & A way of teaching suited to each patient's developmental stage & $8(3)$ & $8(2,2)$ \\
\hline 9 & Understanding the law regarding children and adolescents & $9(1,1)$ & \\
\hline 9 & Nursing care of patients with various disorders & & $9(2,1)$ \\
\hline 9 & The relation of one's department to other departments and specialties. & $9(1,1)$ & \\
\hline 9 & Social resources which children and adolescents can utilize & $9(1,1)$ & \\
\hline 10 & Learning from and acquiring the skills of other staff to care for patients & & $10(1)$ \\
\hline 10 & Promoting patients' positive thinking. & $10(1)$ & \\
\hline
\end{tabular}

$5=$ highest priority; 1 = lowest priority.

importance (from the most important to the least important) the area of their practice that they would like to improve upon. This was achieved by using a voting system followed by rank ordering. Each group member was asked to choose the five most important areas from their master list, and then rank them. All votes were recorded on the flip chart which was clearly visible. After that, the identified areas were discussed by the group members. The same process occurred with the second focus group. The focus groups were 1 and $1 / 2$ hr and 2 hr and 9 min long, respectively.

\section{Data Analysis}

All data were recorded in Japanese and subsequent data were translated into English. To support the trustworthiness and quality assurance of the translation, the researcher had the data translations verified by a master's-prepared bilingual academic who worked in the United Kingdom. The researcher sent six excerpts that the researcher translated into English and asked the academic to translate them back into Japanese. These translations were compared with the original Japanese data.

Data collected from focus group sessions were analyzed by NGT analysis as described previously. The tape recordings were only used as a backup to clarify aspects of the notes (Krueger \& Casey, 2009).

\section{Findings}

Six staff members participated in Focus Group A. All participants were registered nurses aged 30 to 40 years. Participants had an average of 8 years general nursing experience and nearly 1 and $1 / 2$ years experience in child or adolescent mental health settings. This group was the more junior group. In contrast, eight participants attended the Focus Group B session. More than half of the participants were in their 50s, with the other three in their 30s or 40s. Their average nursing experience was nearly 26 years and experience in child or adolescent mental health settings was over 5 and $1 / 2$ years.

In the NGT process, Group A participants presented 22 areas for improvement and as a group they subsequently refined their ideas and made a list of 18 items; of these, 12 areas were ranked. Coincidently, Group B participants also presented 22 areas for improvement, and made a list of 12 items in the same way as Group A. Ten areas were ranked out of 12 areas in Group B. Some of the areas in the two groups overlapped (see Table 1). The top-ranked area in both groups was similar as they expressed their overall need to have more knowledge of child and adolescent mental illness and disorders in order to care for their patients. Learning needs related to dealing with families were ranked second highest in Group A and third highest in Group B. Communication skills was ranked third highest in Group A. In contrast, nursing care of 
patients with developmental disorders was ranked second highest in Group B. These areas all relate to fundamental nursing care within this patient population. There were some areas of practice only one group identified as important to their learning needs. For example, the experienced group identified their need for more education on promoting their patients' independence and their ability to engage them in group play activities. Conversely, the less experienced group considered they needed skills in communication with both patients and their family and relaxation strategies.

\section{Discussion}

The findings indicated that the mental health nurses in this context had wide-ranging learning needs, but of prime importance to them was their need for knowledge in fundamental areas of their everyday work. This was exemplified by their need for more knowledge of child and adolescent mental illness and disorders in order for them to better care for their patients. Being able to incorporate and meet the needs of patients' family was similarly important and they highlighted their need for more knowledge in this area. Nursing care suited to one's patient's developmental stage and teamwork skills were both ranked by the groups. These findings are congruent with those of Jones (2004) whose study was with U.K. mental health nurses, thus indicating the commonalities in this specialty across vastly different cultures and geographical locations.

The highlighted deficits are important to recognize and address. Nurses have an important role in addressing emotional problems and the secondary problems, including a possible decline in patient self-esteem, depressive states, irritability, aggressive behaviors, and delinquency which are experienced by some adolescents with developmental disorders (Tanaka, 2008). In a wider sense, the participants indicated that they needed to learn more or to relearn ways of providing support for patients in these areas, in particular for patients with developmental disorders and abused patients. The less experienced group (Group A) felt they needed more self-confidence and wanted to think more positively about their patients. The experienced group thought more broadly and wanted to improve their skills by learning from others.

It is only when normal parameters of development are understood that one can discern anomalies (Critchley, 1992). By placing clinical observations into a theoretical framework such as a developmental theory, patients' behaviors can be interpreted, and health needs of patients can be identified (Critchley, 1992).

The findings of this research also identified that nurses felt an educational need for them to better support and empathize with their patients' family. A number of approaches can be used to promote a family model of care. The Family
Systems Approach, family life cycle, and the Family Developmental Model are considered to be useful for understanding families (Hiraki, 2008; Kano, 2004; Sergeant, 2009). However, Iida (2008) contests that these theories cannot explain all phenomenon related to family, because families were complicated and changeable. These learning needs identified in this research could be understood from the viewpoint of familycentered care.

Family-centered care refers to ". . . an approach to the planning, delivery, and evaluation of health care that is grounded in mutually beneficial partnerships among health care providers, patients and families" (Ahmann \& Johnson, 2000, p. 88). That is, family members are partners in treatment and/or care and are treated with respect and require support and understanding (Iida, 2008; Kano, 2004; Mitchell \& Chaboyer, 2010). It is inherent in this model of care to involve families in the care and treatment planning for the adolescent patient (Regan, Curtin, \& Vorderer, 2006). Support that nurses can provide for families of hospitalized children consists of effective and meaningful communication, information about their child's condition and treatment, emotional support, and methods to enhance parental self-esteem (Miles, 2003). Family-centered care involves support for family, empathy with family, and family education, and is an area highlighted as problematic in the current study's nurses' knowledge and understanding. Without a comprehensive understanding of one's patient's condition, together with meaningful ways to incorporate families, nurses will not achieve a familycentered care approach. It is therefore imperative that nurses working in adolescent mental health units have additional education to allow them to promote the well-being of their patients and families.

\section{Conclusions}

The educational needs of nurses working in an inpatient adolescent psychiatric ward in Japan were attained by an NGT needs analysis within an Adult Learning Theory framework. The method effectively identified their specific learning needs in this context, demonstrating the utility of NGT as a part of an educational needs analysis within an environment where a hierarchical society exists. NGT ensures that there is an equal weighting placed on each participant's viewpoint.

The findings indicated that a similar situation existed in Japan as was reported in the United Kingdom and that mental health nurses had wide-ranging learning needs which primarily fitted within the realm of fundamental patient care issues. Understanding more about their patients' condition and treatment and how their developmental progress affected this was important. They felt they needed more instruction on incorporating families and meeting their needs. A familycentered care approach is recommended. These learning needs indicate the necessity for more knowledge and infor- 
mation to support clinical decision-making regarding patient care, and also reflected the perceived lack of preparedness felt by these mental health nurses.

\section{References}

Ahmann, E., \& Johnson, B. H. (2000). Family-centered care: Facing the new millennium. Pediatric Nursing, 26(1), 87-90. American Nurses Association. (1994). 看護スタッフ能力開発 の基準 [Standards for nursing staff development].インター ナショナル ナーシングレビュー[International Nursing Review], 17(3), 56-63.

Brennan, M. (2006). An evaluation of perceived education and training needs of staff nurses and care officers. Journal of Forensic Nursing, 2(4), 175-183.

Critchley, D. L. (1992). Role of developmental theory in child and adolescent mental health assessment. In P. West \& C. L. Sieloff Evans (Eds.), Psychiatric and mental health nursing with children and adolescents (pp. 32-49). Gaithersburg, MD: Aspen.

Delbecq, A. L., Van de Ven, A. H., \& Gutsfson, D. H. (1975). Group techniques for program planning: A guide to nominal group and Delphi processes. Glenview, IL: Scott, Foresman and Company.

Dogra, N., \& Vostanis, P. (2007). Providing clinical services for a diverse population: Views on training of child and adolescent mental health practitioners. Journal of Interprofessional Care, 21(6), 645-655.

Funashima, N., Miura, H., \& Kameoka, T. (2005). 病院に就業 する看護師の学習ニードに関連する特性の解明 [Exploration of the attributes related to level of learning needs of hospital-based nurses]. 日本看護学教育学会誌 [Journal of Japanese Academic Nursing Education], 15(2), 13-23.

Hewitt-Taylor, J. (2002). Inside knowledge: Issues in insider research. Nursing Standard, 16(46), 33-35.

Hiraki, N. (2008). 家族を支援するための方法と技術 [A way and technique of supporting a family]. In T. Amagaya, T. Endou, T. Sueyasu, \& F. Yoshihama (Eds.), 実践精神科看護 テキスト:児童思春期精神看護 [Textbook of practical psychiatric nursing: Child and adolescent psychiatric nursing]

9 (pp. 196-211). Tokyo: Psychiatric Mental Health Nursing.

Holloway, I., \& Wheeler, S. (2006). Qualitative research in nursing (2nd ed.) (M. Noguchi, Trans.). Tokyo: Igakushoin. (Original work published 2002).

Iida, J. (2008). 家族支援, 家族療法 [Family support and family therapy]. 精神科治療学 [Psychiatric Treatment], 23(Suppl.), 119-123.

Japanese Nursing Association. (2000). 継続教育の基準 [Standard for continuing education in nursing]. 看護 [Nursing], 52(11), 72-77.

Japanese Nursing Association. (2001). 日本看護協会調查研究 報告書: 1999病院看護基礎調査 [JNA research report: 1999

10 survey on hospital nursing]. Tokyo: Author.

Jones, J. (2004). The post-registration education and training needs of nurses working with children and young people with mental health problems in the UK. London: Royal College of nursing.
Retrieved September 9, 2008, from http://www.rcn.org.uk/ development/publications/ publications

Kano, R. (2004). 家族の精神保健 [Family mental health]. In K. Yamazaki (Ed.), 現代児童青年精神医学 [Contemporary child and youth psychiatry] (pp. 443-449). Osaka, Japan: Nagai Shoten.

Knowles, M. S. (1980). The modern practice of adult education: revised and updated. Chicago: Follett.

Knowles, M. S., Holton, E. F., III \& Swanson, R. A. (2005). The adult learner (6th ed.). London: Elsevier.

Krueger, R. A., \& Casey, M. A. (2009). Focus groups: A practical guide for applied research (4th ed.). London: Sage.

Miles, M. S. (2003). Support for parents during a child's hospitalization. American Journal of Nursing, 103(2), 62-64.

Mitchell, M. L., \& Chaboyer, W. (2010). Family-centred care-A way to connect patients, families and nurses in critical care: A qualitative study using telephone interviews. Intensive and Critical Care Nursing, 26, 154-160.

O’Neil, M. J., \& Jackson, L. (1983). Nominal group technique: A process for initiating curriculum development in higher education. Studies in Higher Education, 8, 129-138.

O'Shea, C., \& Spike, N. (2005). Learning needs analysis: Developing a new tool for general practice training. Australian Family Physician, 34(12), 41-43.

Pedder, L. (1998). Training-needs analysis. Nursing Standard, 13(6), 50-53.

Regan, K. M., Curtin, C., \& Vorderer, L. (2006). Paradigm shifts in inpatient psychiatric care of children: approaching child-and family-centered care. Journal of Child and Adolescent Psychiatric Nursing, 18(1), 29-40.

Saito, K. (2005). 思春期 - 青年期の精神医療:行政の現状と今 後の課題 [Adolescent and youth psychiatric medical service: The present state of administration and issues for the future]. In M. Sakata (Ed.), 精神 看護 エクスペール 15:思春期 · 青年期の精神看護 [Psychiatric nursing expert 15: adolescent and youth psychiatric nursing] (pp. 136-143). Tokyo: Nakayama Shoten.

Sergeant, A. (2009). Working within child and adolescent mental health inpatient services: A practioner's handbook. Wigan, UK: National Workforce Programme Child and Adolescent Mental Health. Retrieved September 20, 2010, from http:// www.chimat.org.uk/ resource/item.aspx?RID $=81580$

Sugiyama, T. (2005). 览童精神科の現状と課題 [The present state and problems of child psychiatry]. In M. Tsujii, M. T. Sugiyama, T. Ujita, K. Takayama, \& S. Yamaoka (Eds.), 発達 障害者支援法ガイドブック [Guide book of developmental disorder person support law] (pp. 212-217). Tokyo: Kawade Shobo.

Tanaka, Y. (2008). 注意欠陥/多動性障害 [Attention deficit/ hyperactivity disorder]. 精神科治療学 [Psychiatric Treatment], 23(Suppl.), 203-208.

World Health Organization. (2005). Atlas: Child and adolescent mental health resources: Global concerns, implications for the future. Retrieved July 10, 2010, from http://www.who.int/ mental_health/resources/Child_ado_atlas.pdf 
JOBNAME: No Job Name PAGE: 6 SESS: 7 OUTPUT: Fri May 25 17:49:34 2012 SUM: 507F2181

/v2503/blackwell/journals/jcap_v0_i0/jcap_335

Assessing the Educational Needs of Mental Health Nurses Working in an Adolescent Inpatient Psychiatric Ward in Japan

Yamazaki, A. (2004). 巟童青年精神医学の歴史と特徵 [history of child and youth psychiatry and its characteristic]. In A. Yamazaki, S. Ushijima, H. Kurita, \& S. Aoki (Eds.), 現代児童 青年精神医学 [The present child and youth psychiatry] (pp. 3-11). Osaka: Nagai Shoten.
Yamazaki, A. (2008). 現代の览童青年精神科医療の課題と展 望 [Current problems and prospects of child and adolescent psychiatry]. In M. Sakata (Ed.), 精神看護エクスペール 12: こどもの精神看護 [Psychiatric nursing expert 12: Child psychiatric nursing] (pp. 11-18). Tokyo: Nakayama Shoten. 